\title{
KUALITAS TERJEMAHAN PROVERB KE DALAM BAHASA INDONESIA MENGGUNAKAN GOOGLE TRANSLATE
}

\author{
Ahmad Muzaki Alawi \\ Universitas Gadjah Mada \\ Kabupaten Sleman, Daerah Istimewa Yogyakarta 55281 \\ Email: alawiezacky13@gmail.com
}

\begin{abstract}
Abstrak
Menerjemahkan tulisan dengan bantuan mesin baik berbasis aplikasi offline maupun online sering dilakukan terutama oleh civitas akademika. Sebuah penelitian lama oleh Aiken dan Ghosh (2009) mengungkapkan bahwa Google Translate (GT) adalah yang paling sering di gunakan untuk menerjemahkan dan paling baik di kelasnya. Hingga September 2017, Google mengumumkan bahwa GT sudah menggunakan sistem saraf neuro sehingga mampu memberikan hasil yang hampir sama dengan terjemahan manusia. Fokus pada penelitian ini adalah bagaimana proverb (peribahasa) diterjemahkan ke dalam bahasa Indonesia menggunakan GT. Peribahasa merupakan hasil produk budaya yang bentuknya baku dan menggunakan leksikon-leksikon spesifik sehingga manusia pun akan kesulitan untuk menerjemahkannya. Penelitian ini dilakukan melalui tiga tahapan: pengumpulan data, analisis data, dan penyajian hasil analisis data. Terdapat 100 peribahasa yang dianalisis tingkat kualitasnya. Sebelumnya, 100 peribahasa tersebut sudah diterjemahkan oleh penerjemah. Hasil terjemahan inilah yang akan menjadi tolok ukur kualitas terjemahan GT. Penelitian ini akan mengungkap akurasi dan sesuai hasil terjemahan proverb ke dalam Bahasa Indonesia dengan menggunakan GT. Berdasarkan data yang diperoleh, terdapat beberapa peribahasa yang diterjemahkan ke dalam bentuk peribahasa bahasa Indonesia. Sebagian besar peribahasa itu dapat dipahami maksudnya meskipun tidak membentuk peribahasa secara akurat. Akan tetapi, terdapat sejumlah kecil penerjemahan GT yang menghasilkan ungkapan yang sulit dipahami dalam bahasa sasaran.

Kata kunci: Proverb, Kesesuaian, Kewajaran
\end{abstract}

\begin{abstract}
Translating articles by using machine either offline or online application is frequently carried out, particularly by the scholars. A study by Aiken and Ghosh (2009) revealed that Google Translate (GT) is considered as mostly machine used due to translate articles. It is also the leading translation machine among others. Until September 2017, Google announced GT has been using nervous system so that it is able to produce the same results as translations done by human translators. The study focused on how proverbs which would have been translated into Indonesian by using GT. Proverbs are cultural elements which have standard pattern and use specific lexicons that human translators might find difficulties due to translate them. The study used three steps: data collections, data analyses, and results presentation. 100 proverbs were analysed based on the level of quality. The translation results would become a benchmark of translation results by using GT. The study demonstrated accuracy and suitability of proverb translation results into Indonesian by using GT. Based on the data, there were several proverbs which were translated into proverbs in Indonesian. Most of the proverbs could be understood, although the proverbs were not accurately translated. Therefore, there were also translation results by using GT which produced proverbs which were hardly be understood into the target language.
\end{abstract}

Keywords: proverb, suitability, accuracy 


\section{PENDAHULUAN}

Menerjemahkan bukanlah hal yang sulit. Terlepas dari baik tidaknya hasil terjemahan, semua orang dapat melakukannya dengan bantuan mesin. Terlebih lagi, Kamus offline sudah dapat diinstal pada smartphone sehingga memudahkan penggunanya dalam proses penerjemahan tanpa membawa kamus konvensional. Selain berbentuk aplikasi offline, masyarakat dapat menggunakan aplikasi dalam jaringan (online). Meskipun menerjemahkan dengan bantuan aplikasi online membutuhkan "kuota data internet", banyak penerjemah yang menggunakannya. Aplikasi online tidak hanya sangat baik dalam menerjemahkan kata per kata, tetapi aplikasi ini juga dapat menerjemahkan dalam bentuk frasa, klausa, kalimat, bahkan paragraf. Aiken dan Ghosh (2009) mengungkapkan bahwa penggunaan Google Translate (GT), mesin penerjemahan berbasis online adalah yang paling banyak digunakan dan paling akurat jika dibandingkan dengan translation machine lainnya.

Pada saat ini, banyak karya tulis fiksi maupun non-fiksi dalam bentuk buku, artikel jurnal, majalah, surat kabar, novel, kumpulan dan bahkan lagu telah diterjemahkan dari bahasa Inggris ke dalam bahasa Indonesia. Jika dilihat secara luas, jumlah hasil terjemahan karya tulis jauh melampaui karya tulis asli penulis
Indonesia. Akan tetapi, apakah banyaknya kuantitas tersebut sepadan dengan kualitas hasil terjemahannya? Tidak sedikit kasus terjadi ketika pembaca harus berfikir dalam untuk memahami kalimat-kalimat yang sudah diterjemahkan tersebut. Kalimatkalimat yang sulit diterjemahkan yang umumnya ditemukan adalah ungkapan idiom, metafora atau peribahasa (proverbs). Peribahasa merupakan bentuk bahasa yang sangat dekat dengan budaya penuturnya. Pada umumnya, peribahasa banyak berupa metafora, ritme bahasa maupun aliterasi. Penggunaan leksikon serta struktur sintaksis peribahasa berbeda dari bahasa satu ke bahasa yang lainnya. Hal ini tentu sangat menyulitkan GT untuk menerjemahkannya

Masalah utama dalam proses penerjemahan adalah mencari padanan (Hartono, 2017: 4). Padanan di sini dapat bervariasi levelnya dari kata sampai kalimat. Secara umum, GT sangat baik, cepat dan memberikan banyak pilihan kata ketika diminta untuk menerjemahkan teks sumber ke teks sasaran dalam bentuk kata atau frasa. Penerjemah biasanya akan menyeleksi pilihan kata yang tepat dalam konteks kalimat yang sedang dia kerjakan. Akan tetapi, GT tidak cukup bagus ketika menerjemahkan klausa atau kalimat, terlebih lagi jika terdapat unsur budaya pada bahasa sumber. Contoh pada kalimat "Hari ini tepat 40 hari kakekku". Ketika kalimat tersebut dialihbahasakan ke dalam Bahasa 
Inggris menggunakan GT, hasilnya menjadi "Today is exactly 40 days my grandfather". Ketika menerjemahkan, GT akan mencari semua kemungkinan kesepadanan dengan menggunakan kode alogaritma pada mesin terjemahan sekaligus membatasi ruang kebahasaan yang lebih khusus pada bahasa sasaran pada waktu yang bersamaan.

Peribahasa merupakan bentuk bahasa yang sangat dekat dengan budaya penuturnya. Holman dan Harmon dalam Hartono (2017: 107) mengatakan bahwa peribahasa adalah perkataan yang mengungkapkan suatu pengakuan kebenaran tentang kehidupan. Pada umumnya, peribahasa banyak berupa metafora, ritme bahasa maupun aliterasi. Penggunaan leksikon serta struktur sintaksis peribahasa berbeda dari bahasa satu ke bahasa yang lainnya. Hal ini tentu sangat menyulitkan GT untuk menerjemahkannya.

Bagaimana dengan penerjemahan yang dilakukan oleh GT? Seperti terjemahan mesin lainnya, GT tidak memiliki ideologi, metode ataupun strategi untuk menerjemahkan. Google Translate hanya menggunakan alogaritma yang sudah diformulakan dan cenderung mengambil secara acak kata yang menurutnya paling tepat kemudian dimasukan ke dalam bahasa sasaran tanpa perlu memikirkan tata bahasa yang berlaku. Dengan sering dilakukannya perkembangan oleh tim, GT sekarang jauh lebih baik daripada sebelumnya, bahkan jika dibandingkan dengan penerjemah amatir, hasil terjemahan GT bisa jadi lebih bagus. Sebagai contoh proverb "where there is a will, there is a way' dapat langsung diterjemahkan menjadi 'dimana ada kemauan disitu ada jalan' oleh GT. Hasil terjemahan tersebut ternyata sangat akurat dan sama persis dengan terjemahan manusia. Bagaimanapun juga, terdapat peribahasa yang diterjemahkan oleh GT dengan tingkat kualitas buruk. Seperti proverb 'the tongue wounds more than a lance' diterjemahkan oleh GT menjadi 'Lidah luka lebih dari tombak'. Setelah diterjemahkan oleh manusia, hasilnya menjadi 'lidah lebih tajam daripada pedang'.

Beberapa pakar penerjemahan memiliki definisi yang berbeda mengenai penerjemahan. Nida (1982: 12) mengatakan bahwa menerjemahkan berarti memproduksi padanan yang paling dekat dan wajar dengan pesan yang ingin disampaikan bahasa sumber, pertama yang berhubungan dengan arti, yang kedua berhubungan dengan gaya. Definisi ini terdengar sangat bebas karena ukuran yang penting dari menerjemah adalah tersampaikannya makna atau tidak. Benarkah penerjemahkan hanya sekadar menyampaikan makna pesan? Bagaimana dengan kedudukan tata bahasa yang 
berterima dan konteks social pada bahasa sasaran?

Catford (1978: 20) menyatakan bahwa penerjemahan adalah penggantian material teks bahasa sumber dengan material teks bahasa sasaran yang sepadan. Dia mengatakan "Translation is the replacement of textual material in one language (SL) by equivalent textual material in another language (TL)." Pengertian ini lebih spesifik daripada yang dikemukakan oleh Nida di atas. Dalam hal ini penerjemah harus mampu mengganti atau menempatkan kembali informasi teks sumber dengan informasi yang sepadan pada teks sasaran.

Proverb menurut Oxford Advanced learner's Dictionary merupakan frasa atau kalimat yang menyampaikan pesan atau sesuatu yang benar pada umumnya. Bentuk proverb berbeda dengan idiom. Contoh proverb adalah "It is no use crying over a spilled milk". Makna dari proverb tersebut memiliki pesan bahwa yang sudah terjadi biarlah terjadi dan tidak perlu disesali. Berbeda dengan kalimat "It's raining cats and dogs." Kalimat tersebut bukanlah proverb, melainkan idiom. Kalimat tersebut tidak menunjukkan pesan tersirat di dalamnya. Ia hanya menyatakan ungkapan untuk hujan yang turun dengan sangat lebat.

Peribahasa sendiri menurut Utami (2013:102) merupakan kalimat atau penggalan kalimat yang telah membeku bentuk, makna, dan fungsinya dalam masyarakat; bersifat turun temurun; dipergunakan untuk penghias karangan atau percakapan, penguat maksud karangan, pemberi nasihat, pengajaran, atau pedoman hidup. Selain itu, dijelaskan pula ciri-ciri peribahasa yang biasanya menggunakan perumpamaan atau perbandingan. Perumpamaan tersebut merupakan kiasan yang mengandung makna tersembunyi. Jenis-jenis peribahasa mencakup bidal, pepatah, perumpamaan, ibarat, dan pemeo.

Holman dan Harmon (1992:380) mengatakan bahwa peribahasa adalah perkataan yang mengungkapkan suatu pengakuan kebenaran tentang kehidupan. Menurut Hartono (2017:107), penerjemahan peribahasa sanagat membutuhkan kecakapan penerjemah untuk mencari padanan peribahasa dalam bahasa sasaran yang sesuai dengan konteks sosiokulturnya. Oleh karenanya, terjemahan peribahasa dalam teks ssasaran biasanya sangat jauh berbeda bentuknya dengan peribahasa dalam teks sumber. Dalam hal ini, Ekasari (2005:7) memberikan contoh peribahasa " $A$ bad workman always blames his tools." Peribahasa tersebut kemudian diterjemahkan ke dalam Bahasa Indonesia menjadi “Buruk muka cermin dibelah.” Jika dilihat dari segi bentuk, tidak terdapat leksikon yang sepadan antara bahasa sumber dan bahasa sasaran. Akan tetapi, secara makna, bahasa sasaran memiliki nilai budaya dan lebih dapat dipahami oleh 


\section{KUALITAS TERJEMAHAN PROVERB KE DALAM BAHASA INDONESIA MENGGUNAKAN GOOGLE TRANSLATE}

penuturnya dibanding jika diterjemahkan menjadi "Pekerja yang buruk selalu menyalahkan peralatannya.

Sesuatu hal dianggap berkualitas dan baik apabila memenuhi beberapa kriteria. Larson (1991:532) berpendapat bahwa setidaknya ada tiga kriteria untuk menilai kualitas terjemahan. Yang pertama adalah akurasi (accuracy) berhubungan dengan apakah terjemahannya sudah mengkomunikasikan makna yang sama dengan makna yang terdapat pada teks sumber atau belum, dan apakah makna yang ditangkap pembaca teks sumber sama dengan yang dipahami oleh pembaca teks sasaran. Kedua, keterbacaan (readability) dipahami sebagai teks terjemahan menggunakan bahasa yang elegan, sederhana, dan mudah dimengerti. Ketiga, kewajaran (naturalness) artinya teks terjemahan mudah dibaca dan menggunakan tata bahasa yang wajar dan lazim sesuai dengan tata bahasa atau gaya bahasa penutur bahasa sasaran.

Berkaitan dengan kriteria penilaian hasil terjemahan, Albir (2001:283) mengusulkan empat prinsip dasar yang harus diperhatikan:

a. Penguji (evaluator) harus setia terhadap kriteria yang ditetapkan dan yang diuji (evaluaee) harus sadar terhadap kriteria yang ada.

b. Kriteria penilaian bergantung pada konteks (jenis teks yang diterjemahkan) dan fungsi penilaian (jenis teks yang digunakan), sehingga harus dipertimbangkan mengapa, untuk apa dan untuk siapa penilaian itu dilakukan.

c. Objek penilaian (apa yang sedang dinilai). Di sini penilai harus mempertimbangkan apa yang seharusnya dan dapat dia evaluasi.

d. Penilai atau penguji hasil terjemahan seharusnya mempertimbangkan beberapa indikator.

Melihat kriteria di atas, ketika meneliti kualitas penerjemahan diperlukan juga adanya skala-skala tertentu sebagai indikator apakah hasil terjemahan dapat dikategorikan baik atau tidak. Hartono (2017: 57) mengemukakan tabel skala penilaian kualitas terjemahan sebagai berikut: 
Tabel 1. Skala Penilaian Kualitas Terjemahan

\begin{tabular}{|c|c|l|}
\hline Kategori & Nilai & \multicolumn{1}{c|}{ Indikator } \\
\hline $\begin{array}{c}\text { Hampir } \\
\text { sempurna }\end{array}$ & $86-90$ & $\begin{array}{l}\text { Tidak ada distorsi makna; penyampaian wajar; hampir tidak } \\
\text { seperti terjemahan; tidak ada kesalahan ejaan; tidak ada } \\
\text { kesalahan/penyimpangan tata bahasa; tidak ada kekeliruan } \\
\text { penggunaan istilah. }\end{array}$ \\
\hline Sangat bagus & $76-85$ & $\begin{array}{l}\text { Tidak ada distorsi makna; tidak ada terjemahan harfiah yang } \\
\text { kaku; tidak ada kekeliruan penggunaan istilah; ada satu-dua } \\
\text { kesalahan tata bahasa/ ejaan. }\end{array}$ \\
\hline Baik & $61-75$ & $\begin{array}{l}\text { Tidak ada distorsi makna; ada terjemahan harfiah yang kaku, } \\
\text { tetapi relatif tidak lebih dari 15\% keseluruhan teks, sehingga } \\
\text { tidak terasa seperti terjemahan; kesalahan idiom dan tata bahasa } \\
\text { tidak lebih dari 15\% keseluruhan teks; ada satu-dua penggunaan } \\
\text { istilah yang tidak umum/baku; ada satu-dua kesalahan ejaan. }\end{array}$ \\
\hline Cukup & $46-60$ & $\begin{array}{l}\text { Terasa sebagai terjemahan; ada beberapa terjemahan harfiah } \\
\text { yang kaku, tetapi relatif tidak lebih dari 25\% keseluruhan teks; } \\
\text { ada satu-dua penggunaan istilah yang tidak umum/baku } \\
\text { dan/atau kurang jelas. }\end{array}$ \\
\hline Buruk & $20-45$ & $\begin{array}{l}\text { Sangat terasa sebagai terjemahan; terlalu banyak terjemahan } \\
\text { harfiah yang kaku (relative lebih dari 25\% keseluruhan teks); } \\
\text { distorsi makna dan kekeliruan penggunaan istilah lebih dari } \\
\text { 25\% keseluruhan teks. }\end{array}$ \\
\hline
\end{tabular}

Kesesuaian hasil terjemahan GT dalam penelitian ini diuji dengan menggunakan model tingkat kesesuaian yang digunakan oleh Memsource (Hartono, 2017: 60), dengan angka kesesuaian sebagai berikut:

Match 100 : hasil terjemahan identik dengan HT, tanpa perlu penyuntingan.

Match 76-95 : hasil terjemahan mendekati sempurna, perlu sedikit penyuntingan.

Match 50-75 : hasil terjemahan memerlukan perbaikan pada kata-kata, harus disunting.
Match 00-49 : hasil terjemahan masih jauh dan cenderung tidak sesuai.

Adapun tingkat kewajaran dapat dianalisis dengan menggunakan naturalness-rating instrument milik Nababan (2004: 61-92).

Tabel 2. Skala Penilaian Tingkat Kewajaran

\begin{tabular}{|c|c|c|c|c|c|}
\hline \multirow{2}{*}{ No } & \multirow{2}{*}{$\begin{array}{c}\text { Hasil } \\
\text { Terjemahan GT }\end{array}$} & \multicolumn{4}{|c|}{ Tingkat } \\
\cline { 3 - 6 } & & $\mathbf{4}$ & $\mathbf{3}$ & $\mathbf{2}$ & $\mathbf{1}$ \\
\hline 1 & & & & & \\
\hline 2 & & & & & \\
\hline 3 & & & & & \\
\hline dst & & & & & \\
\hline \multicolumn{3}{|c|}{ Terkait dengan } & peribahasa dalam
\end{tabular}

bahasa Indonesia, beberapa penelitian pernah dilakukan. Salah satunya adalah disertasi yang ditulis oleh Sailal Arimi (2016) berjudul Peribahasa Indonesia: 


\section{KUALITAS TERJEMAHAN PROVERB KE DALAM BAHASA INDONESIA MENGGUNAKAN GOOGLE TRANSLATE}

Kajian Kategorisasi, Struktur, dan Vitalitasnya. Penelitian tersebut menghasilkan ciri-ciri peribahasa yang berkonstruksi frasa dan kalimat, berbentuk kesepakatan tetap, berrelasi proposisional, bermakna figurative dan literal, berpesan kearifan, berkognisi kolektif, bernilai masa lalu, berdaya waris, berupa paremiological minimum, berfungsi khusus dan berupa kutipan.

Penelitian selanjutnya adalah tesis yang dilakukan oleh Nur Lailatul Aqromi berjudul Penggunaan Kata Api dalam Peribahasa Bahasa Inggris dan Bahasa Indonesia: Analisis Semantik Kognitif. Penelitian tersebut menunjukkan cara berfikir atau kognisi masyarakat tentang kata api dalam peribahasa mereka. Kata api dalam bahasa Inggris dapat bermakna nasihat atau pujian. Sedangkan dalam bahasa Indonesia, kata api selalu berkonotasi negatif dan biasanya mengungkapkan sindiran atau sifat yang jelek pada manusia seperti amarah. Dari sini dapat disimpulkan bahwa peribahasa selalu menggunakan leksikon yang berbeda dalam setiap bahasa dan leksikon yang sama dan tidak selalu bermakna dan menggambarkan hal sama dalam dua atau lebih bahasa.

Penelitian tentang akurasi GT pernah dilakukan oleh Mikam Aiken dan Shilpa Balan (2011) yang berjudul An Analysis of Google Translate Accuracy. Penelitian tersebut mengungkapkan bahwa penerjemahan bahasa-bahasa Eropa dengan menggunakan GT sangatlah bagus, sedangkan pada bahasa-bahasa Asia tergolong kurang baik. Penelitian lain juga dilakukan oleh Balk EM dkk (2013) dalam jurnal yang berjudul Assessing the Accuracy of Google Translate to Allow Data Extraction from Trials Published in NonEnglish Languages. Hasil penelitian tersebut mengungkapkan bahwa penerjemahan bahasa Inggris ke dalam bahasa Spanyol menduduki akurasi tertinggi dan bahasa Inggris ke dalam bahasa Cina menduduki yang terendah. Penelitian tersebut juga menerangkan bahwa GT berpotensi mengurangi bias dalam bahasa. Namun, penerjemah harus tetap teliti dalam menggunakannya.

Pada halaman online review teknologi MIT (2016), diungkapkan bahwa keterbacaan terjemahan GT hampir sama dengan hasil terjemahan yang dilakukan oleh penerjemah manusia. Artinya, hasil terjemahan GT dalam beberapa aspek sudah sangat bagus. Bahkan, ketika beberapa orang yang lancar dalam dua bahasa diminta untuk membandingkan hasil terjemahan Google dengan penerjemah, mereka sama sekali tidak melihat banyak perbedaan. Sejak September 2017, GT sudah menggunakan artificial intellegence (AI) atau integensi buatan yang memungkinnya 
lebih cepat dan lebih akurat dalam menerjemahkan. Penerjemahan dari bahasa Inggris ke bahasa Spanyol atau bahasa Perancis memiliki tingkat akurasi hampir $100 \%$.

Penelitian yang dilakukan oleh Tya Vidhayasai dkk (2015) yang meneliti kesalahan penerjemahan "Terms and Conditions" pada halaman website sebuah maskapai penerbangan di Vietnam mengungkapkan bahwa kesalahan banyak terjadi pada tingkat leksikon. Dalam level ini, sering tidak ditemukan padanan yang tepat dalam bahasa Vietnam. Pada tingkat leksikon kemudian dapat dilihat bahwa ternyata leksikon yang mengandung idiomatic expression yang paling banyak ditemukan kesalahan.

Penelitian tentang kualitas penerjemahan mesin juga dilakukan oleh Lucia Specia dkk (2017). Penelitian tersebut fokus pada bahasa-bahasa yang kaya akan proses morfologi. Bahasa-bahasa tersebut adalah Bahasa Inggris, Bahasa German, Bahasa Republik Cheko, Dan Bahasa Latvia. dari keempat bahasa tersebut, penerjemahan dari Bahasa Inggris ke Bahasa Latvia mengalami paling banyak kesalahan dibanding Bahasa German dan Bahasa Cheko. Penerjemahan dengan menggunakan GT menjadi hal yang lazim dilakukan. Berangkat dari fenomena inilah, penulis bermaksud untuk mengobservasi nilai kewajaran dan kesesuaian penerjemahan peribahasa dari Bahasa Indonesia ke dalam Bahasa Inggris menggunakan GT.

\section{METODE}

Dalam penelitian ini, terdapat tiga tahapan utama, yaitu (1) pengumpulan data, (2) analisis data, dan (3) penyajian hasil analisis data. Ketiga tahapan tersebut akan dijelaskan sebagai berikut.

\section{Pengumpulan Data}

Sudaryanto (1993: 5-6) mengatakan bahwa dalam penelitian diperlukan penjaringan data yang merupakan tahap pertama. Pada tahap ini peneliti menyediakan data yang secukupnya untuk kemudian dianalisis. Objek dalam penelitian ini merupakan hasil terjemahan proverb yang dilakukan oleh Google Translate (GT). Proverb dipilih karena bentuknya yang baku, menggunakan ungkapan, serta menunjukan ciri khas dari bahasa dan penggunanya.

Adapun pemilihan proverb diambil dengan menggunakan teknik purposive sampling dimana sampel diambil dengan beberapa pertimbangan tertentu (Sugiyono, 2012: 68). Proverb yang dipilih sudah diterjemahkan oleh Hana Melita Sari (2005). Perlunya hasil terjemahan manusia adalah untuk digunakan sebagai pembanding dengan hasil terjemahan GT pada tahap analisis data. Dari sejumlah data, 
dipilih 150 proverb dalam bahasa Inggris yang kemudian diterjemahkan ke dalam bahasa Indonesia menggunakan GT.

\section{Analisis Data}

Kesuma (2007: 47) mengatakan bahwa tahap analisis data dapat dilaksanakan setelah data dikumpulkan dan diklasifikasikan. Klasifikasi data dalam penelitian ini adalah hasil terjemahan yang dilakukan oleh GT. Data tersebut kemudian dinilai tingkat kesepadanannya dan kewajarannya. Tingkat kesepadanan dilakukan dengan menggunakan skala matching (kesesuaian) yang dikemukakan oleh Memsource (Hartono, 2017: 60) seperti yang sudah disebutkan pada tabel bagian landasan teori.

Adapun kewajaran akan diuji dengan menggunakan kuisioner yang diberikan kepada 5 mahasiswa pascasarjana Ilmu Linguistik di Universitas Gadjah Mada sebagai responden. Isi kuisioner tersebut merupakan tabel 2 yang sudah diuraikan pada subbab sebelumnya, yaitu naturalnessrating instrument milik Nababan (2004: 6192). Kelima responden tersebut diminta untuk memberi nilai hasil terjemahan GT tanpa mengetahui bahasa sumbernya. Hal ini dimaksudkan agar mereka dapat lebih objektif dalam menilai makna kalimatkalimat terjemahan tersebut. Pada tahap ini, hasil terjemahan akan dianalisis apakah maknanya sudah tersampaikan atau belum terlepas dari hasil terjeman berbentuk peribahasa atau bukan.

\section{Penyajian Hasil Analisis Data}

Tahap ini merupakan tahap terakhir dalam penelitian. Dalam penelitian ini, data disajikan secara informal. Kesuma (2007: 71) menjelaskan bahwa dalam penyajian informal, data disajikan dan dijelaskan menggunakan leksikon-leksikon biasa. Dalam hal ini, penyajian data secara informal terwujud dalam penjelasan deskripsi dan mengapa terjadi hasil yang seperti itu.

\section{HASIL DAN PEMBAHASAN}

\section{Kesesuaian Terjemahan GT}

Kesesuaian hasil terjemahan GT dalam penelitian ini diuji dengan menggunakan model tingkat kesesuaian yang digunakan oleh Memsource, dengan angka kesesuaian sebagai berikut:
Match 100 : hasil terjemahan identik dengan HT, tanpa perlu penyuntingan.

Match 76-95 : hasil terjemahan mendekati sempurna, perlu sedikit penyuntingan.
Match 50-75 : hasil terjemahan memerlukan perbaikan pada kata-kata, harus disunting.


Match 00-49 : hasil terjemahan masih jauh dan cenderung tidak sesuai.

Dari 100 peribahasa yang dipilih, terdapat 24 peribahasa yang dapat diterjemahkan oleh GT dengan tingkat kesesuaian match 100. Berikut disajikan beberapa contoh terjemahan GT dengan tingkat kesesuaian match 100 :

(1) Home sweet home: rumahku surgaku

(2) A little better than none: sedikit lebih baik daripada tidak sama sekali

Hasil terjemahan dalam teks sasaran dengan menggunakan GT sama persis dengan hasil terjemahan HT. Dari data di atas dapat terlihat bahwa GT sudah tidak menerjemahkan dengan hanya sekadar alih bahasa kata per kata. Namun, ia memperhatikan tata bahasa yang baik pada teks sasaran. Hal ini terlihat pada pemilihan kata 'surga' pada contoh nomor (1) dan pergeseran frasa menjadi kalimat pada contoh (2).

Hasil analisis juga menunjukkan terdapat 42 proverbs yang diterjemahkan GT dengan tingkat kesesuaian 75-95. Perhatikan contoh data berikut:

(3) Patience brings rewards: kesabaran membawa imbalan

(4) An empty barrel resounds loudly: sebuah tong kosong bergema keras

(5) Like two drops of water: seperti dua tetes air

Hasil terjemahan GT di atas menggunakan tata Bahasa Indonesia yang benar dan dapat dipahami maknanya. Namun, kalimat-kalimat tersebut bukanlah peribahasa. Tidak terdapat nilai-nilai luhur dari pilihan kata-kata tersebut. Hasil tersebut dapat dikatakan kurang baik karena makna budaya tidak dapat ditransfer ke dalam bahasa sasaran. Berikut kami tunjukkan hasil terjemahan HT sebagai pembanding:

(6) Patience brings rewards: orang sabar disayang tuhan

(7) An empty barrel resounds loudly: tong kosong nyaring bunyinya

(8) Like two drops of water: bagai pinang dibelah dua

Pada contoh no (6), (7), dan (8), penerjemah mencari padanan peribahasa yang sepadan dalam bahasa sasaran. Ketiga hasil terjemahan tersebut memiliki kesatuan bahasa yang utuh serta menggunakan leksikon yang sesuai dalam Bahasa Indonesia. Meskipun contoh (7) memiliki kata inti yang sama yaitu tong kosong, akan tetapi semua kata dalam kalimat tersebut tidak dapat diganti; berbeda dengan contoh (4).

Temuan lain dalam analisis adalah hasil terjemahan GT benar secara gramatikal dan dapat dipahami secara makna, tetapi dirasa aneh oleh pembaca bahkan ada yang maknanya sulit dimengerti. Perhatikan contoh berikut: 


\section{KUALITAS TERJEMAHAN PROVERB KE DALAM BAHASA INDONESIA MENGGUNAKAN GOOGLE TRANSLATE}

(9) A friend in need is a friend indeed: seorang teman yang membutuhkan adalah seorang teman.

(10)An empty purse frightens away friends: dompet kosong membuat takut teman

Hasil terjemahan GT di atas berdasarkan pada alogaritma kata per kata yang kemudian digabungkan dengan mempertimbangkan kaidah gramatikal dalam Bahasa Indonesia. Pada contoh no (9) hasil terjemahan justru membingungkan pembaca. Sedangkan pada (10) tidak memiliki hubungan antara dompet yang kosong dan teman yang takut. Kedua peribahasa di atas akan menjadi lebih mudah dipahami seperti berikut:

(11) A friend in need is a friend indeed: teman sehidup semati

(12) An empty purse frightens away friends: ada uang abang sayang

Pada contoh (11) dan (12) sebenarnya bukan merupakan peribahasa. Kedua kalimat tersebut merupakan ungkapan. Hal ini membuktikan bahwa sebenarnya peribahasa tidak harus diterjemahkan menjadi peribahasa juga dalam bahasa sasaran. Jika memang tidak terdapat peribahasa yang sesuai, maka penerjemah dapat mengunakan ungkapan-ungkapan yang sering dipakai dan mudah dipahami oleh pembaca.

Temuan terakhir pada tingkat kesesuaian adalah terdapat 34 hasil terjemahan proverbs yang tidak dapat dipahami. Hasil tersebut perlu disunting ulang sehingga menjadi lebih bermakna. Perhatikan contoh data berikut:

(13) After a storm comes a calm: Setelah badai datang dengan tenang.

(14) Honey is sweet but the bee stings: Madu itu manis, tapi sengatan lebah.

Contoh data-data di atas salah secara gramatikal. Tidak hanya makna kontekstualnya, makna secara leksikalnya pun sulit dipahami. Hal ini disebabkan GT belum mampu mendeteksi gaya bahasa pada tata Bahasa Inggris yaitu penggunaan pola $\mathrm{V}$ + S seperti 'comes a calm' pada contoh (13). Kemudian pada contoh (13) juga dapat dilihat bahwa GT kurang mampu membedakan kata yang berbentuk sama ketika menduduki kategori verba dan nomina seperti 'stings'.

\section{Kewajaran Terjemahan GT}

Menilai kewajaran terjemahan berarti melihat apakah bentuk hasil terjemahan sudah alamiah atau tepat dengan gaya bahasa sasaran atau belum (Hartono, 2017: 50). Uji kewajaran pada penelitian ini dengan menggunakan lembar observasi yang diberikan kepada 30 mahasiswa pascasarjana Ilmu Linguistik UGM. Para responden diminta untuk membaca dan memberi nilai apakah maknanya sudah dapat dipahami serta disampaikan secara 
wajar atau tidak. Dalam hal ini, mereka tidak tahu bahwa kalimat-kalimat yang mereka nilai merupakan terjemahan proverb oleh GT. Kewajaran menurut Larson (1984: 497) dapat dilihat dari pilihan kata dan bentuk kalimat yang lumrah terdapat dalam bahasa sasaran.

Dari 100 hasil terjemahan proverbs oleh GT, responden menilai terdapat 41 terjemahan yang tidak wajar baik dari pilihan kata maupun bentuk kalimatnya. Hal itu dibuktikan dari jawaban responden yang menyatakan bahwa mereka perlu berfikir ulang untuk memahami kalimat-kalimat tersebut. Bahkan, ada beberapa kalimat yang tidak dapat dipahami sama sekali maksudnya karena pilihan leksikon yang tidak sesuai dengan konteks dalam bahasa Indonesia. Berikut disajikan beberapa contoh data hasil terjemahan yang tidak wajar.

(15) Pin bigger than pole: Pin lebih besar dari kutub

(16) Like chicken, no paw, no eat: Seperti ayam, tanpa cakar, tidak makan

Pada contoh data (15) kata 'pin' diterjemahkan oleh GT menjadi pin dalam Bahasa Indonesia. Kata ini merujuk pada sesuatu yang dipakai dalam berpakaian oleh wanita. Ketika kata 'pin' diketik pada GT, hasil terjemahan pin merupakan kata pertama yang disarankan. Sedangkan kata kutub, yang merupakan terjemahan dari 'pole', merupakan kata ketiga yang disarankan oleh GT. Padahal, kata pertama yang muncul justru lebih wajar, yaitu tiang. Hal ini menunjukkan bahwa GT tidak selalu memilih kata pertama yang muncul untuk ketika menerjemahkan. Sedangkan pada contoh (16) pilihan leksikonnya sudah wajar dalam konteks Bahasa Indonesia. Namun tanpa cakar akan menimbulkan makna bahwa ayam tersebut tidak memiliki cakar. Hal inilah yang membuat hasil terjemahan tersebut menjadi tidak wajar.

Sisanya, yaitu 59 hasil terjemahan proverbs oleh GT, dinilai sangat wajar oleh responden. Pilihan kata dan bentuk kalimatnya sudah sesuai dengan tata bahasa dalam Bahasa Indonesia. Meskipun beberapa hasil terjemahan bukan merupakan peribahasa, namun kalimat-kalimat tersebut dapat dipahami maknanya oleh pembaca tanpa harus mengernyitkan dahi untuk berpikir. Berikut disajikan beberapa contoh data yang bukan peribahasa tetapi wajar pada bentuk dan maknanya.

(17) Building castlein the air: Membangun istana di udara

(18) Forbidden fruit is sweet: Buah terlarang itu manis

\section{KESIMPULAN}

Dibandingkan dengan terjemahan manusia atau Human Translation, nilai kesesuaian hasil terjemahan Proverbs oleh 


\section{KUALITAS TERJEMAHAN PROVERB KE DALAM BAHASA INDONESIA MENGGUNAKAN GOOGLE TRANSLATE}

GT dikatakan baik. Bahkan beberapa ada yang sama persis dengan HT. Adapun tingkat kewajaran hasil terjemahan GT dinilai cukup baik kurang menurut responden. Berdasarkan datayang diperoleh, 59\% hasil terjemahan dianggap menggunakan pilihan kata dan bentuk kalimat sesuai dengan bahasa Indonesia menurut responden. Meskipun terdapat kata yang tidak wajar digunakan sebagai perumpamaan dalam bahasa Indonesia, namun kalimat-kalimat yang mengandun kata tersebut masih dapat dipahami maknanya oleh pembaca. Meskipun begitu, secara keseluruhan penerjemah yang menggunakan bantuan mesin terutama GT perlu untuk menyunting kembali hasil terjemahannya sehingga menjadi lebih wajar dan sesuai dengan konteks budaya yang ada dalam masayarakat Indonesia.

\section{DAFTAR PUSTAKA}

Aiken, M., Ghosh, K., Wee, J., and Vanjani, M. (2010a). Aiken, M., Ghosh, K., Wee, J., and Vanjani, M. (2009a). An evaluation of the accuracy of online translation systems. Communications of the IIMA, 9(4), 6784. Communications of the IIMA, 9(4), 67-84, in press. http://findarticles.com/p/article s/mi_7099/is_4_9/ai_n56337599/

Aqromi, N.L. 2015. Tesis: Penggunaan Kata Api dalam Peribahasa Bahasa Inggris dan Bahasa Indonesia: Analisis Semantik Kognitif. Yogyakarta: Universitas Gadjah Mada.
Arimi, Sailal. 2016. Disertasi: Peribahasa Indonesia, Kajian Kategorisasi, Struktur, dan Vitalitasnya. Yogyakarta: Universitas Gadjah Mada.

Catford, J.C. 1978. A Linguistic Theory of Translation: Theory and Practice. London: Longman Group UK Limited.

Ekasari, H.M. 2005. Popular English Proverbs. Yogyakarta: Penerbit Pustaka Widyatama.

Hartono, Rudi. 2017. Pengantar Ilmu Menerjemah. Semarang: Cipta Prima Nusantara.

Larson, M.L. 1984. Meaning-Based Translation: A Guide to Crosslanguage Equivalence. Lanham: University Press of America.

MIT Review. 2016. Google's Neural Machine Translation System: Bridging the Gap between Human and Machine Translation. https://arxiv.org/abs/1609.08144

Nababan, M. R. 2003. Teori Menerjemah Bahasa Inggris. Yogyakarta: Pustaka Pelajar.

Nida, E. A. dan Taber, C.R. 1982. The theory and Practice of Translation. Leiden: E.J. Brill.

Soemarno, T. 1993. "Studi tentang Kesalahan Terjemahan dari Bahasa Inggris ke dalam Bahasa Indonesia" (oleh Mahasiswa yang Berbahasa Ibu Bahasa Jawa). Unpublished Thesis. Malang: Institut Keguruan dan Ilmu Pendidikan Malang.

Specia, Lucia. Dkk. 2017. Transaltion Qualitry and Productivity: A Study on Rich Morphology Languages. Sheffield: Proceedings of MT Summit XVI, Vol 1.

Sudaryanto. 1993. Metode dan Teknik Analisis Bahasa: Pengantar Penelitian Wahana Kebudayaan Secara Linguistis. Yogyakarta: ILDEP Duta Wacana University Press

Sugiyono. 2012. Metode Penelitian Kuantitatif Kualitatif dan $R \& D$. Bandung: Alfabeta. 
Sugiyono. 2015. Metode Penelitian Kuantitatif, Kualitatif, dan $R \& D$. Bandung: AFABETA

Utami, N.S. 2013. Pintar Pantun Puisi Puisi Peribahasa dan Majas. Yogyakarta: Naafi' Book Media.
Vidayashi, dkk. 2015. Investigating the Use of Google Translate in "Terms and Conditions" in an Airline's Official Website: Errors and Implications. Vietnam: King Mongkut's University of Technology Thonburi. diakses tanggal 08 Oktober 2018. 